\title{
RAYONISM IN EARLY MODERN ART - A FLEETING RAY OF LIGHT
}

Mikail PUŞKİN*

\begin{abstract}
Current research paper explores the fleeting Russian avant-garde artistic movement of the first half of the $20^{\text {th }}$ century known as Rayonism (Rayism or Luchizm). Comparative formalist and conceptual analysis with its contemporary movements and predecessors (Cubo-Futurism, Orphism, Cubism, Futurism) are chosen as the main methods of research as permitting some clarity based on the objectively observable elements while remaining aware of ideological connotations. The article opens up with the introduction of the movement and then proceeds with comparative analysis infused with relevant elements of historical and ideological context highlighting evident similarities and distinct unique features of Rayonism as art and idea. The article is concluded with discussion of possible reasons for the (inevitable) decline of the movement (trauma of the main artists, lack of provocative edge) as well as its conceptual weaknesses (lack of genuine innovation). Its role in the greater context of the artistic world evolution is attributed to the reconceptualization of the role of artist as scientist and providing a shift from objective representation towards pure abstraction.
\end{abstract}

Keywords: Russian Avant-garde, Rayonism, Orphism, Futurism, Cubism

ERKEN MODERN SANATTA RAYONIZZM - KISACIK BİR IŞIK IŞINI

Öz

Bu çalışmada, Rayonizm (Rayism veya Luchizm) olarak bilinen 20. yüzyılın ilk yarısının geçici Rus avangart sanatsal hareketi araştııılmaktadır. İdeolojik çağrışımların farkında kalırken nesnel olarak gözlemlenebilir unsurlara dayanan bir miktar netliğe izin veren çağdaş hareketler ve öncülleriyle (Cubo-Fütürizm, Orfizm, Kübizm, Fütürizm) karşılaştırmalı biçimci ve kavramsal analizler ana araştırma yöntemleri olarak seçilmiştir. Çalışma, hareketin tanıtılmasıyla başlamakta ve ardından Rayonizmin sanat ve fikir olarak belirgin benzerliklerini ve farklı benzersiz özelliklerini vurgulayan tarihsel ve ideolojik bağlamın ilgili unsurları ile aşılanmış karşılaştırmalı analizlerle devam etmekte ve hareketin (kaçınılmaz olarak) düşüşünün olası nedenlerinin (ana sanatçıların travması, kışkırtıcı üstünlüğün olmaması) ve kavramsal zayıflıklarının (gerçek yeniliklerin olmaması) tartışılmasıyla sona ermektedir. Çalışma, sanatsal dünya evriminin daha geniş bağlamındaki rolüne sanatçının bilim insanı olarak rolünün yeniden kavramsallaştırılmasına ve nesnel temsilden saf soyutlamaya doğru bir geçiş sağlaması bakımından önem taşımaktadır.

Anahtar Kelimeler: Rus Avangard, Rayonizm, Orfizm, Fütürizm, Kübizm.

Atıf: PUŞKIN, M. (2021). "Erken Modern Sanatta Rayonizm - Kısacık Bir Işık Işını”, İMGELEM, 5 (9): 313327.

Citation: PUŞKIN, M. (2021). "Rayonism in Early Modern Art - A Fleeting Ray of Light", IMGGELEM, 5 (9): 313-327.

Başvuru / Received: 25 Ağustos / August 2021.

Kabul / Accepted: 4 Kasım / November 2021.

Derleme Makale / Review Article.

\section{INTRODUCTION}

The social environment of the first half of the $20^{\text {th }}$ century proved to be a fertile soil for a wide range of (modern) art movements not only in the West but also in the East of Europe. An abundance of movements and styles both interconnected and conflicting inescapably caused confusion aggravated by the fact that some artists switched between the styles, experimented

\footnotetext{
* Dr. Öğr. Üyesi, Ağrı İbrahim Çeçen Üniversitesi, Fen-Edebiyat Fakültesi, Sosyoloji Bölümü, Genel Sosyoloji ve Metodoloji Anabilim Dalı, E-mail: pushkin169@gmail.com, ORCID Number: 0000-0003-0467-1699
} 
by integrating elements of various styles, belonged to several artistic movements at the same time, got mislabeled, etc. This necessitates deciphering the differences and identifying common traits of the art movements. Current research paper provides comparative analysis of Russian avant-garde art movement named Rayonism with its predecessors and contemporaries (CuboFuturism, Orphism, Cubism, Futurism). Structurally, it opens with a brief introduction to Rayonism and provides several peculiar points on how it is particular. It then proceeds with comparative analysis of the movement with its identifiable roots and coexisting styles that influenced it. Where necessary, historical context is brought into focus. Such comparison provides for a better insight into the movement itself. The ultimate goal of the paper is to identify the elements that influenced the particular pattern of success of this movement, ones that perhaps had a negative influence on its perception by contemporaries and the following generations. The research also considers the elements that Rayonism brought into the art scene, which survived the movement itself. The paper concludes with the results of the conducted research.

\section{What is Rayonism?}

Among the various movements of the early Russian avant-garde, Rayonism (also known as Luchizm or Rayism) stands aside in many ways. Although originated as early as 1909 with Larionov's painting "Glass", the style has not been introduced to the artistic community up until 1913 at the "Target" exhibition, when the manifesto written a year prior has been made public. Interestingly, the painting was possibly backdated by Larionov in his attempt to obscure Rayonist roots in Italian Futurism.

"While it can't be denied that in later years some of Russia's literary Futurists tried to forestall any doubts about their originality by obscuring the dates of their early publications, it is important to note that the Italian painting manifestos and the full impact of Futurist painting itself appeared somewhat later than Marinetti's first manifesto, so that it is quite certain that whatever effect they had on Russian painting was superimposed on an already lively interest in the new theories of art from France and Germany" (Douglas 1975: 229-230).

The new movement has rapidly succeeded in gaining popularity, however, has only lasted for under two years. In 1914 "Larionov was drafted into the army. He was injured in the battle of the Masurian Lakes and spent three months in a hospital. The injury affected his ability to concentrate and resulted in the decline of his artistic energy" (Barok 2020). Whether it was the consequence of Larionov's injury or the following immigration of his and Goncharova's to 
France is debatable, but Rayonism ceased to exist by 1915. Although a distinctive style, it has never truly been largely practiced by artists aside from the family of its creators - Michael Larionov and Natalya Goncharova. This lack of following and a short success span make it appear in retrospective as a bright flash on the horizon of Russian art scene on the verge of pure abstract art epoch.

One of the more efficient ways to proceed with visual and conceptual analysis is by comparing a movement to its predecessors and co-occurring movements, rather than describing it on its own. Rayonism has a number of clearly identifiable avant-garde roots, all traceable in its artworks: Cubism, Futurism and Orphism. Furthermore, Rayonism is also known in some sources as Cubo-Futurism: "two of the first Cubo-Futurist artists, Larionov and Goncharova, merged elements of Russian folk art and modern French art in their effort to preserve Russian folk art" (Dietrich 2018: 6). Such attribution is however, misleading, as Cubo-Futurism preceded Rayonism.

\section{Cubo-Futurism and Rayonism}

The term Cubo-Futurism was "first used in 1913 in a lecture, later published, by the Russian art critic Korney Chukovsky" (Parton 2003), though elements of artistic style appeared in Goncharova's works as early as 1909, which focused on reinterpretation of cubist techniques with their somewhat rigid concepts of objects fragmentation. However, it added the movement and daring colors of Futurism, partially even mocking predecessors with folk motives (the cow in example) vastly common for Russian avant-garde. Rayonism, in contrast, constructed objects from rays of light, rather than fragmenting them into cubes and focused on the color and force elements of Futurism more than on the movement. Rayonism also featured a consistent framework expressed in manifesto, while Cubo-Futurism was not so centralized and specific. 


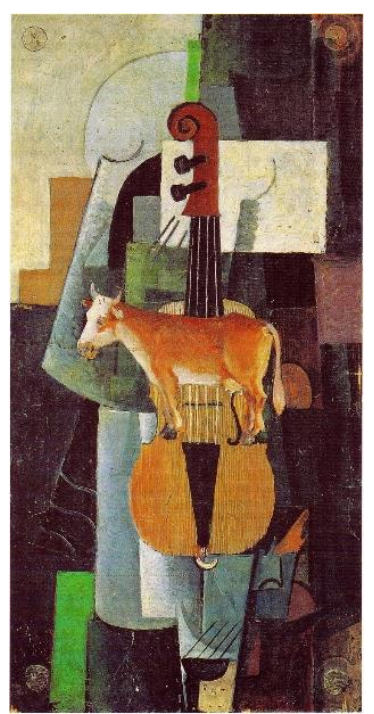

Figure 1

Kazimir Malevich, Cow and Fiddle, 1913. Wood, oil, The State Russian Museum, SaintPetersburg

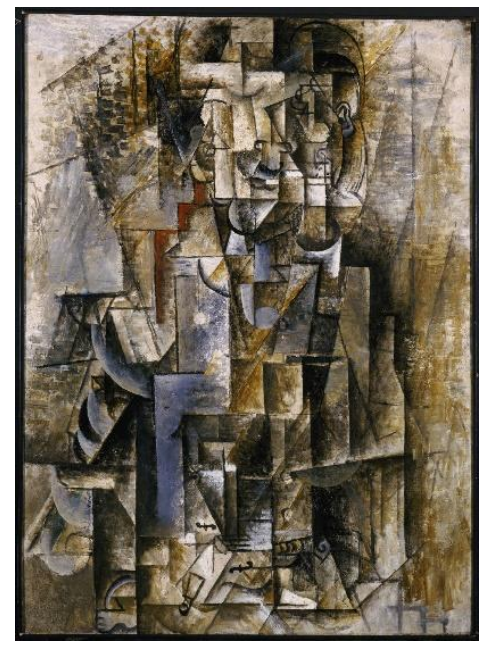

Figure 4

Man with a Violin,

Pablo Ruiz y Picasso,

1911-1912.

Oil on canvas,

Estate of Pablo Picasso,

New York

Comparing the two given paintings

even on the superficial level, one can clearly

notice the pronounced decentralized character

of the Rayonist composition as well as the use

of irregular geometric forms in it.

Furthermore, "Green and Yellow Forest",

Figure 1, possesses the notion of movement,

expressed through the semi-chaotic arrangement of elements and the "traces"

particularly evident with the yellow section

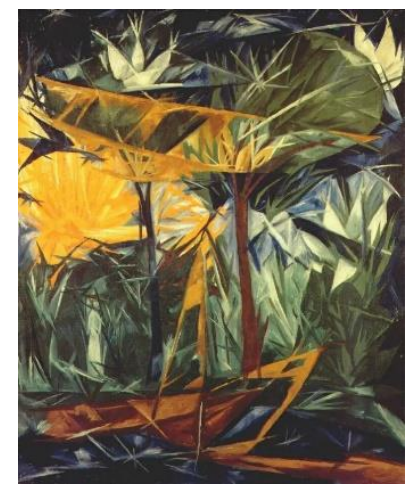

\section{Figure 2}

Yellow and Green Forest,

Natalia Goncharova, 1913.

Oil on canvas, Staatsgalerie above the middle. Whereas "Cow and Fiddle", Figure 2, is still rigid and centralized, with much more regular polygonal shapes, just like the cubist works it was somewhat mocking. Malevich's work is clearly referential to variations of "Violin" paintings by Braque and Picasso, Figure 3, Figure 4, which makes it difficult to claim Cubo-Futurism as a distinctively new movement. There are also Cubo-Futuristic works with brighter color palette, more

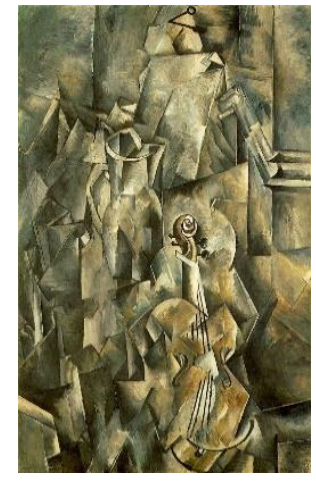

Figure 3

Violin and pitcher, Georges Braque, 1910.

Kunstmuseum Basel, Basel abstract arrangement and more evident movement element, like "The Knifegrinder or Principle of Glittering”, Figure 5, however, the geometric shapes used in construction appear similar. Rayonist painting, in comparison is almost purely abstract and innovative in a wide range of aspects: concepts of objects, colors, composition, movement, space (dimensionality).

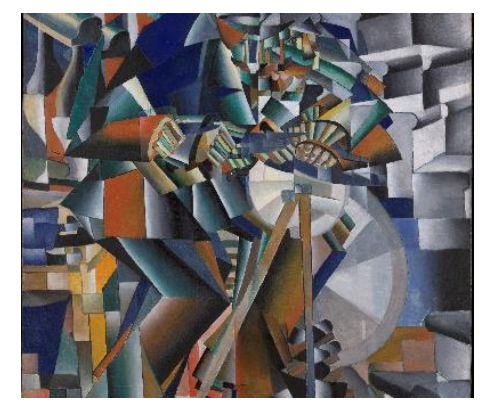

Figure 5

The Knifegrinder or Principle of Glittering,

Kazimir Malevich, 1912-13.

Oil on canvas,

Yale University Art Gallery,

New Haven

\section{Orphism and Rayonism}

Amongst the aforementioned styles, Orphism (also sometimes referred to as OrphoCubism) stands, perhaps the closest to Rayonism, literally in all aspects. The very core of 
Orphism with the title coined by Guillaume Apollinaire in 1912, France, consisted of very few people and the movement is commonly attributed to Sonya and Robert Delaunay (a family couple, like with Rayonist key figures). Like Rayonism, it only lasted a few years: between 1911 and 1914. There is, however a certain share of controversy surrounding the attribution of artists to this movement. Although the Puteaux Group is used sometimes synonymously with Orphism, - their uniform attribution to its stated principles is possibly misleading. A third artist working with Delaunays can likewise be credited as the founder of Orphism is František Kupka, who however denied the critic's definition of Orphic Cubism leading to his exclusion from the critic's works.

"Guillaume Apollinaire [...] first used the word Orphism at the 1912 Salon de la Section d'Or. [...] Some accounts, including Kupka's, said he first used the word to refer to Kupka's Amorpha works. [...] Apollinaire wrote extensively on Orphism, though he sometimes varied his terminology, as in his 1913 essay, "Quartering Cubism" where he referred to "Orphic Cubism", [...] "from cubism there emerges a new cubism. The reign of Orpheus is beginning" (Apollinaire 1913 cited in Seiferle: 2021). Indeed, in this essay, he divided Cubism into four categories, although his categorization of painters within the different categories was somewhat arbitrary. Kupka resisted his inclusion in Apollinaire's definition of Orphism, finding it simplistic. He insisted that "in 1911, I created my own uniquely 'abstract' way of painting, Orphism, disregarding all other cultural systems except that of Greece" (Apollinaire 1911 cited in Seiferle: 2021).

Similarly, among the artists working in Rayonist style only few names are identifiable: "In Russland arbeiten auser Larionov, Alexander Schewtchenko, Michail Le Dantu und Sergej Romanowitsch auf rayonistische weise" (Kowtun 1998: 136). There also does not seem to be much controversy with attribution, save for calling some of Goncharova's works Rayonist or Cubo-Futurist depending on the source.

There is a certain lack of information regarding the link between Orphists and Rayonists, beyond mentioning that Larionov has most likely been familiar with their works. Therefore, it is debatable, whether Rayonism really developed out of Orphism, or it was a co-development, considering the time of their appearance and earlier Rayonist works of Larionov before the manifesto.

Both styles can be characterized as emphasizing the role of colors and approaching the depiction thereof from a science-based perspective. However, while for Rayonism colors are 
used as means to depict rays "The ray is depicted provisionally on the surface by a colored line" (Larionov \& Goncharova 1913: 2), becoming in themselves representational of the artist's vision of the object "The objects that we see in life play no role here, but that which is the essence of painting itself can be shown here best of all--the combination of color, its saturation, the relation of colored masses, depth, texture.” (Larionov \& Goncharova 1913: 2). For Orphism, color really is the central figure: "The essential discovery of Orphism was proclaimed as a realization that "color is both form and subject." After an exquisite series of "Windows", Delaunay freed himself from representation and based his designs on the effects of simultaneous color contrast” (Gowing 2019).

Even the scientific elements of Rayonism and Orphism illustrate a different conceptual paradigm and approach. For Orphism, according to Delaunay, "In painting contrasts that form the structure ... and not is form and subject. It is the sole theme that psychological or otherwise. Color is a function ... I used the scientific word of Chevreul: 'the one would express himself in" (Delaunay 1913 cited in Chipp 1958: 61). In other words, a specific scientific paradigm is implemented based on Michel Eugène Chevreul's E la loi du contraste simultanée des couleurs (On the law of the simultaneous contrast of colors) of 1839.

Rayonism, however, illuminates a forthcoming theme of an artist as the scientist of image, constructing the scientific aura of its content through the very wording: "The sum of rays from object $A$ intersects the sum of rays from object $B$; in the space between them a certain form appears, and this is isolated by the artist's will..." (Larionov \& Goncharova 1913: 2). The conceptual paradigm, presented in the manifesto could have been formed earlier - around the time of "The Glass" creation, nonetheless, its formulation and semi-scientific rhetoric method could have come from a specific context in the field of photography: According to John E. Bowlt, Larionov and Goncharova's Rayonist theory could have drawn upon the developments in photography: "[In] 1912-13 the Moscow photographer A. Trapani invented the photographic technique of "ray gum" - a version of the gum-arabic process - which enabled the photographer to create the illusion of a radial, fragmented texture..." (Bowlt 1988: 92-93). Furthermore, if one were to look back to an even earlier time - one would find a very close source not only of manifesto's contents, but of the whole style, which is also the major critique of it on the plagiarism grounds. "Of possible relevance to Larionov's theory of Rayonism was the peculiarly "broken" texture that Mikhail Vrubel favored in so many of his works in the 1890s and 1900s [...]. Moreover, Vrubel's theory of visual reality came very close to Larionov's formulation, as 
the following statement by Vrubel would indicate: "The contours with which artists normally delineate the confines of a form in actual fact do not exist - they are merely an optical illusion

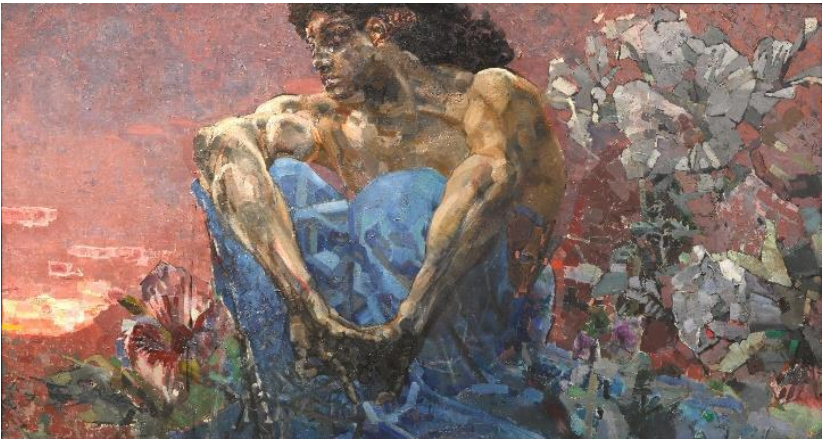

Figure 6

The Demon Seated, Mikhail Vrubel, 1890. Oil on canvas, Tretyakov Gallery, Moscow that occurs from the interaction of rays falling onto the object and reflected from its surface at different angles. In fact, at this point you get a 'complementary color' complementary to the basic, local color..." (Vrubel 1958 referenced in Bowlt 1988: 9293). One can pay close attention to the background to the right from the "The

Demon Seated", Figure 6, which is very similar to Rayonist abstraction, albeit not as sharp with angles of rays and less intense in color.

If one could look at Orphism and Rayonism from perspective of two similar currents situated at the break-even age of the objective and representational art becoming abstract and

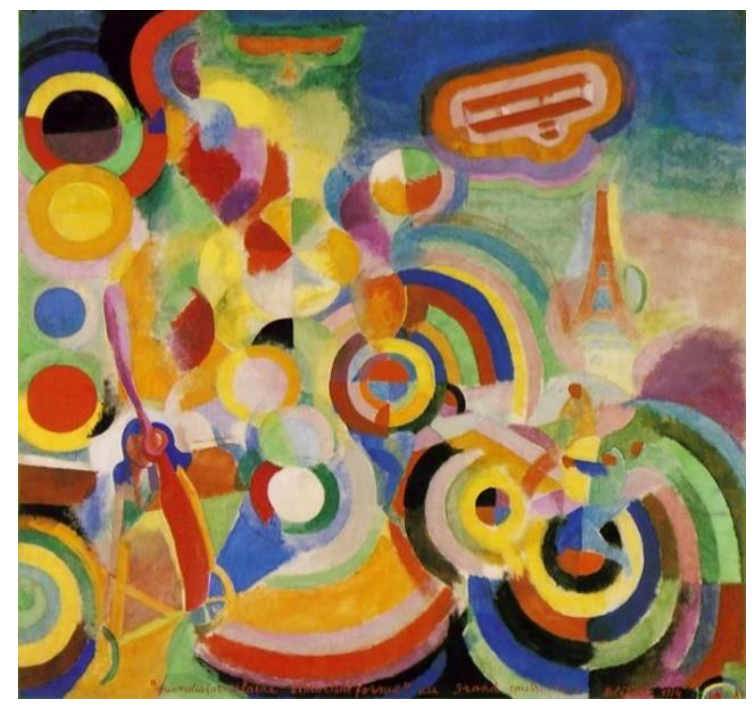

Figure 7

Hommage à Blériot, Robert Delaunay, 1914, Glue tempera on canvas, Kunstmuseum Basel, Basel none-representational (in the objective sense), one could probably position Orphism in the first half and Rayonism - pointing to the future one. Although both styles later shifted into pure abstraction, and have predecessors (Cezanne for Orphism, Fauvists for Rayonism) one can still contrast them as visionaries of a different future: the image of an artist-scientist-constructor (of objects from rays they reflect) with artistmusician-poet (which is clear from the very reference to Orpheus). In a way it can be seen as an opposition between senses and logic.

The stylistic technical difference is also clearly evident in the images, where Rayonists are almost exclusively limited to the use of angles, straight lines and sharp shapes, Orphists seem to be more unrestricted and softer in terms of the use of forms, shapes and colors (which identifies closer link between Rayonism and Futurism). The difference in terms of dissimilar degrees in diversity of the elements is perhaps determined by the adherence to the manifesto on the side of Rayonists and lack thereof for Orphists, since even the members of the movement are not definitely identifiable. 
The opposition is rather clear - both paintings are abstract, however, Rayonist painting is sharper, more radical in the clash of color-forces even with the title containing the word "Domination", Figure 8. Orphist work is softer, shapes are round and colors communicate different emotional image - that of euphoria as opposed to struggle. Furthermore, in the background of "Hommage à Blériot”, Figure 7, one can notice Eifel Tower,

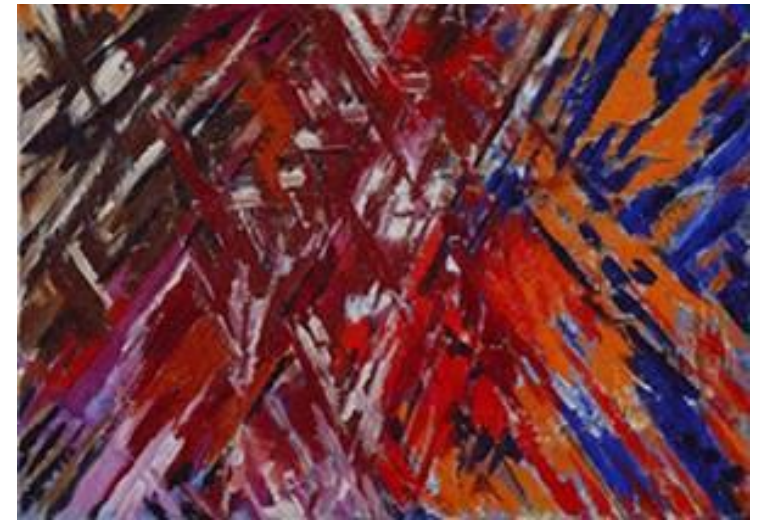

Figure 8

Rayonist Composition: Domination of Red, Mikhail Larionov, 1912-13 (dated on painting 1911). Oil on canvas, Museum of Modern Art, New York and a certain propeller to the front left, while "Domination of Red" features only colors, lines and a certain heavy materiality of the paint, but no objects. This is opposed by the light, although not absent of presence oil paint of Delaunay's painting. Both paintings are dimensional, however, dimensions of Orphism are dimensions of objects and planes, while those of Rayonism are dimensions of rays intertwining and piercing each other with every line of color.

\section{Cubism and Rayonism}

The cubist relation is very clear - it determined the formal properties to the extent of introducing representation of objects through reassembling and portraying from various perspectives at a time. Similarly, Rayonism is deconstructing an object into a set of rays that it reflects, therefore permitting the artist to depict an object regardless of the perspective or point of view consideration, since rays are both reflected and altered by various surfaces and the will of the artist. "Consequently, if we wish to paint literally what we see, then we must paint the sum of rays reflected from the object. But in order to receive the total sum of rays from the desired object, we must select them deliberately - because together with the rays of the object being perceived, there also fall into our range of vision reflected reflex rays belonging to other nearby objects. Now, if we wish to depict an object exactly as we see it, then we must depict also these reflex rays belonging to other objects - and then we will depict literally what we see ...” (Larionov 1913: 97). By introducing new ideas into the climate of Cubism and linking it with the notions of the $4^{\text {th }}$ dimension, an entirely new kind of analytic deconstruction, suggesting a vision of the world, created through the rays of light more real than their real appearance, because the result is created through the artists will (similar to Mondrian's ideas about expressing the human soul through his abstract paintings). The idea of the 4rth dimension in general was no less important for the artists at that time than the "manifesto mania" or "-isms 
mania", however much more useful in terms of generating new conceptual ideas (while manifestos were most useful for the spreading of ideas). Despite a common misinterpretation of the mathematical conception, the notion of other scientifically proven additional superdimension found a large resonance and fountain of fresh reinterpretations in artistic environment. The $4^{\text {th }}$ (or $\mathrm{n}$-th for some) dimension was seen as the one where all objects are perceived at the same time, or where time itself is one of the dimensions and all objects and their actions exist in this dimension at the same time, as a spiritual kind of reality, which artist can perceive and depict. For Rayonism this reality is a particular multidimensional (definitely not the flat canvas 2 dimensions, but many more) space, where not the objects, but rays of force (light) exist - rays are not bound by time or space therefore, alternation in terms of time and space is evident in paintings linking the various ideas of the $\mathrm{n}$-th dimension in one concept and making them subject to artists' will (an almost theosophical parallel). One could perhaps, suggest an analogy, although partially a mocking one, to Plato's idea of people (artists) sitting in a cave and seeing not the objects, but their shadows (rays) reflected upon the wall and then painting them, however, shadows are dimensional and time, like the rays, is floating in various directions. "Perception, not of the object itself, but of the sum of rays from it, is, by its very nature, much closer to the symbolic surface of the picture than is the object itself" (Larionov 1913: 97). This denial of an object in favor of the rays coming from it is already a manifestation of the shift towards pure abstraction, where the object itself becomes unnecessary and eventually disappears.

Comparing "Castle at la Roche-Guyon" Figure 9, and the "Cats (rayist percep.[tion] in

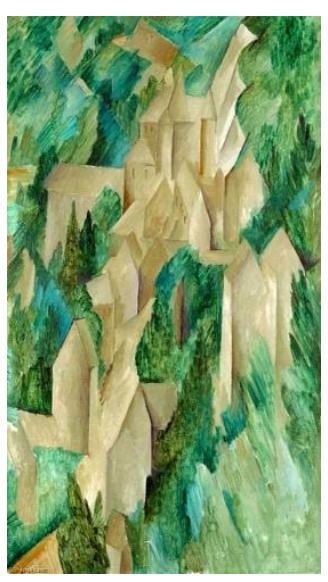

Figure 9

La Roche-Guyon, The Castle, Georges Braque, 1909. Oil on canvas, Moderna Museet, rose, black, and yellow)", Figure 10, one can clearly see a shift towards more abstract vision. While cubist example offers a recompilation of a very wellrecognizable type of an object - a castle surrounded by the green of the forest; Rayonism provides a picture of decompiled objects (cats) conveying the impression of the depicted animals through the non-uniformly directed color lines and angles. There is a certain

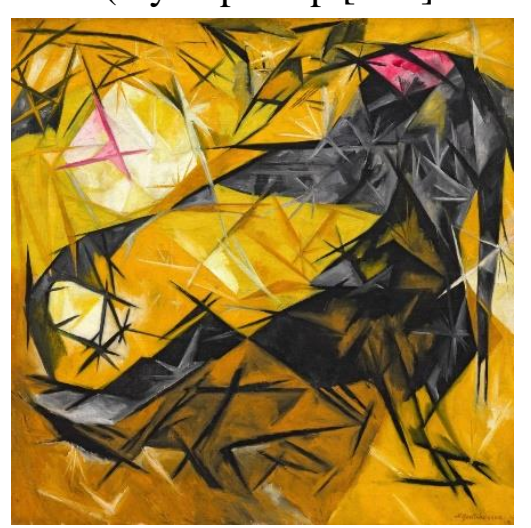

Figure 10

Cats (rayist percep.[tion] in rose, black, and yellow), Natalia Goncharova, 1913.

Oil on canvas,

Solomon R. Guggenheim Museum, New York similarity in terms of space organization, since the figures in Braque's work are slightly aligned 
in the direction from lower left to upper right corner and decentralized. Similarly, decentralized depiction features in Goncharova's painting. There is also a hint to directions, although they are represented in various incomplete ellipsis figures of the cat's bodies. It also features a clear visual opposition - the dark of the "imposing" cat to the bottom-right and the shine of the light source (moon or sun?) closer to the upper-left corner. "Cats (rayist percep.[tion] in rose, black, and yellow)" is furthermore conveying a sense of motion of the figures and the space itself through smeared strokes and "sparks" of white as if reflected in a crystal of a glass. Braque's painting, although not static, conveys impression of trees moved by the wind through their clear directedness, which is in a sense mimetic. The color palette used in Goncharova's work is much more vivid and associative (perhaps reminiscent of the famous Steinlen's "Chat Noir", Figure 11). Comparing to "naturalistic" coloring of "Castle at la Roche-Guyon", it features a whole new degree of abstraction, though is also somewhat "lyrical" in the subject matter. Braque's work furthermore, features a very careful and detailed technique of depiction, although not strictly mimetic, in which it is somewhat reminiscent of impressionist works.

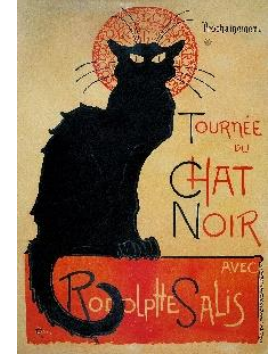

Figure 11

Tournée du chat noir, Theophile Alexandre Steinlen, 1896. Zimmerli Art Museum at Rutgers University, New Brunswick

\section{Futurism and Rayonism}

This establishes a smooth link to the influence of Futurism, which has already partially surfaced earlier with its particular attention to movement, force and industrialization of space. Historically it was introduced to Russian art scene in 1912 with an art-group Hylaea and its rather radical manifesto "A slap in the face of public taste", similar in content to Italian one, but, not to its honor, full of hatred directed at particular writers in person (Bunin, Dostoyevsky...). Ideologically Larionov took from them the idea of establishing a new cannon and a new artist role concept, however, without as much loathing towards the old ways: "it represented the true freeing of art from the former realistic conventions that had oppressed the artistic community" (Larionov 1913: 78). 


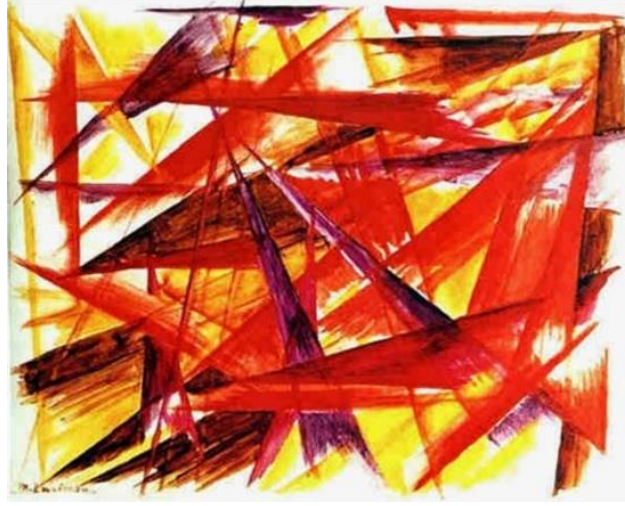

Figure 12

Red Rayonism, Mikhail Larionov, 1913. Watercolor on paper, The Merzinger collection, Switzerland

Similarly to Futurism in painting, the rays of Rayonism are in constant motion, and movement is a reoccurring theme in the paintings. It is either the chaos of rays resembling moving factory lights "Red Rayonism", Figure 12 or an expression of brim and sunlit cockerel spreading its fiery wings in agitated motion also emphasized by doubling of his head, as if already shifted in space and time (paradoxically though, this blurred second head is counter to how it should have been in case of the right to left movement, illustrating the new dimension concept) Figure 13. Comparing to the "Armored train" by Severini, Figure 14, which is largely cubist in approach to objects (but not in style of depiction), a

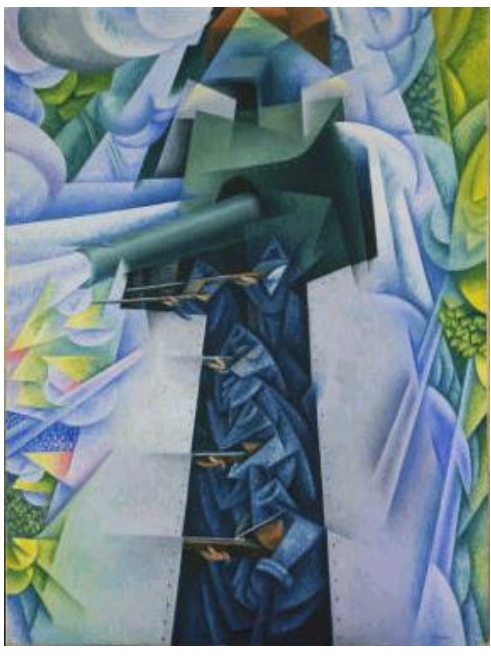

Figure 14

Armored Train in Action, Gino Severini, 1915. Oil on canvas, The Museum of Modern Art, New York

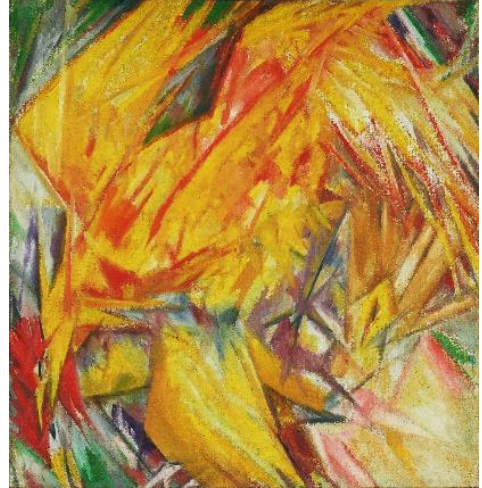

Figure 13

The Cockerel: A Rayonist Study, Mikhail Larionov, 1912.

The State Tretyakov Gallery, progress towards different Moscow dimension with its own time and space is evident in rayonist works.

Considering the ideological part, Rayonism differed from Futurism in a sense of being non-violent and much less industrial in thematic. Instead Rayonism commonly featured impressions of animals, plants, trees and objects before shifting to complete abstraction, thus ridding itself of association with fascism, or industrialization of people. Despite being a revolutionary style in the context of Russian avant-garde (but not so innovative if Vrubel is considered), and personal rebellious acts of Larionov ("In 1910, Larionov was expelled by the Moscow School of Painting for organizing a demonstration against the school's teaching methods." (Barok 2020), Rayonism managed to strip Futurism of its negative associations.

Speaking more about folk notions and nature motives, which are intertwined in Russian avant-garde, one should notice that they are interested in a different kind of common folk comparing to Europeans: factory workers for the latter as opposed to villagers for the former. From hence a substantial amount of nature and county pets come into painting (like in an earlier 
example of "Cow and Fiddle"). Avant-garde in Russia inherited a vast range of European techniques and ideas, born in and adapted mainly to city life, without so much of urban-centrism in subject matter (in this sense more similar to Impressionists and Post-Impressionists).

\section{CONCLUSION}

Despite the positive progressive impression that one might get from the brief comparison, Rayonism did not last long. Reasons are quite diverse with one of the key ones being Larionov getting wounded in the war and being then unable to continue painting (or losing interest). His and Goncharova's leaving for Paris in 1915, never to return to Russia (a country, which also disappeared around that time). Their change of interests from painting to theater costumes and decorations design. This essentially left the painting movement without its ideological leaders and rooted it out of the context in which it

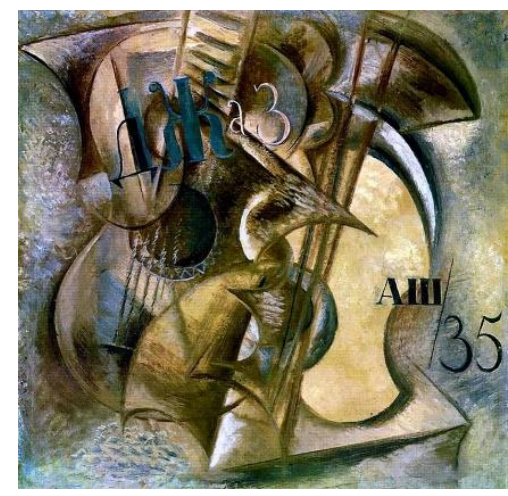

Figure 15

Jazz, Alexander Vasilyevich Shevchenko, 1935. Oil on cardboard, Russian Museum, Saint-Petersburg was born instead of having it evolve.

Among other members, who could have continued the style, the most prominent figure was, perhaps, Le Dantu. However, establishing of a new artistic core through him has never happened, since he died in 1917 during the war. Another member, - Alexandr Shevchenko did not follow with this style and instead joined VKHUTEMAS, his paintings also did not inherit the ideas of Rayonism and instead went into the direction of Cubo-Futurism, as seen in "Jazz", Figure 15.

One of the main reasons for the movement's decline was also the spirit of the time, which required a new kind of art that Rayonism has provided the "seeds" for: pure abstract art. Despite the object being deconstructed and then reconstructed in a ray form on the canvas, - it was stated in the manifesto as present, therefore even when the objective representation disappeared from Rayonist paintings, it was still there in theory, and a shift to theory becoming at times more important than artworks was evident (to name Malevich's "White square on white" for example). A wide range of Rayonist works also feature quite specific references to objects and scenery elements. The ideas regarding the new dimension of vectors of force in the ray form are hinted at but not fully explored, neither is the element of the time.

Furthermore, Vrubel's earlier theory offered most of what Rayonism was concerned with, but in an older art language, so that contemporaries perhaps did not feel significantly 
inspired by the debatable freshness of Larionov's manifesto despite a considerable difference in the terminology and resulting paintings.

What was, perhaps, most important and what survived far into Soviet Union times was the implied role of the artist as a conscious constructor of new reality based on scientific knowledge (optics and photography) if only on canvas for Rayonism. Less than a decade later artists like Tatlin would take the triangular semi-abstract figures into reality with "Monument to the Third International", Figure 16,

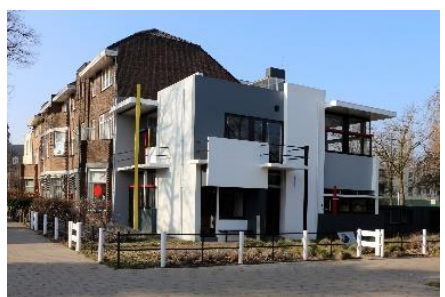

Figure 17

Shroeder House, Gerrit Rietveld, 1924. Utrecht and would furthermore charge them with new political ideology and propaganda. While De Stjil architect Gerrit Rietveld, whose vision was that of lines and colors rather than rays, took the idea of

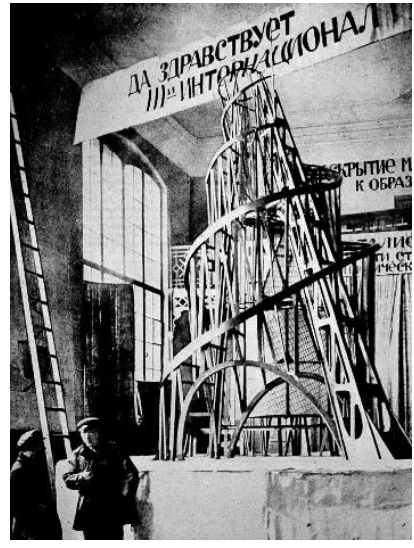

Figure 16

Monument to the Third International, Vladimir Tatlin, 1920. Saint-

Petersburg conceptual perspective into its material realization with the "Rietveld-Schröder" house project, Figure 17.

Furthermore, a certain passiveness in the Rayonist manifesto lacked the propensity to shock the public and create an outcry. Neither did it carry on with aggressive rhetoric of Futurism, nor did it dwell on the notion of new kind of politicized artist.

It steps ahead in terms of visual elements and claims superiority of the new vision abstracted from the depicted objects by description of their rays, however, it is still talking about description and essentially a large number of paintings feature recognizable objects, somewhat pinning Rayonism to an earlier epoch of representative artworks (of genres like still life or landscape). 


\section{REFERENCES}

Barok, D. (2020). Lariónov Mikhail Fiódorovich. - Monoskop. https://monoskop.org/Mikhail_Larionov, 23 September 2020.

Bowlt, J. E. (1988). Russian Art of the Avant-Garde: Theory and Criticism. New York: Thames and Hudson.

Chipp, H. B. (1958). Orphism and Color Theory, The Art Bulletin, 40 (1), 55-63.

Dietrich, A. (2018, 17 Ağustos). Russian culture - 20th century. - Humanities Institute. http://humanitiesinstitute.org/assets/russia46246.culture.20.pdf

Douglas, C. (1975). The New Russian Art and Italian Futurism, Art Journal, 34 (3), 229-239.

Gowing, L. (2019, 1 Kasim). Cubism and its consequences. - Encyclopaedia Britannica. https://www.britannica.com/art/Western-painting/Cubism-and-its-consequences

Kowtun, J. (1998). Michail Larionow 1881-1964, Bournemouth: Parkstone Press.

Larionov, M. (1913). Rayonist Painting, Moscow: The Donkey's Tail and Target.

Larionov, M., Goncharova, N. (1913). Rayonists and Futurists: A Manifesto, Moscow: Oslinyj Khvost i Mishen.

Parton, A. (2003). Cubo-Futurism. - Grove Art Online.

Seiferle, R. (2021). Orphism Movement Overview and Analysis. - TheArtStory.org. https://www.theartstory.org/movement/orphism/history-and-concepts

\section{ARTWORKS}

Figure 3: Yellow and Green Forest, Natalia Goncharova, 1913. Oil on canvas, Staatsgalerie Stuttgart, Stuttgart

Figure 4: Kazimir Malevich, Cow and Fiddle, 1913. Wood, oil, The State Russian Museum, Saint-Petersburg

Figure 3: Violin and pitcher, Georges Braque, 1910. Kunstmuseum Basel, Basel

Figure 4: Man with a Violin, Pablo Ruiz y Picasso, 1911-1912. Oil on canvas, Estate of Pablo Picasso, New York

Figure 5: The Knifegrinder or Principle of Glittering, Kazimir Malevich, 1912-13. Oil on canvas, Yale University Art Gallery, New Haven

Figure 6: The Demon Seated, Mikhail Vrubel, 1890. Oil on canvas, Tretyakov Gallery, Moscow

Figure 7: Hommage à Blériot, Robert Delaunay, 1914. Glue tempera on canvas, Kunstmuseum Basel, Basel

Figure 8: Rayonist Composition: Domination of Red, Mikhail Larionov, 1912-13 (dated on painting 1911). Oil on canvas, Museum of Modern Art, New York

Figure 9: La Roche-Guyon, The Castle, Georges Braque, 1909. Oil on canvas, Moderna Museet, Stockholm

Figure 10: Cats (rayist percep.[tion] in rose, black, and yellow), Natalia Goncharova, 1913. Oil on canvas, Solomon R. Guggenheim Museum, New York

Figure 11: Tournée du chat noir, Theophile Alexandre Steinlen, 1896. Zimmerli Art Museum 
at Rutgers University, New Brunswick

Figure 12: Red Rayonism, Mikhail Larionov, 1913. Watercolor on paper, The Merzinger collection, Switzerland

Figure 13: The Cockerel: A Rayonist Study, Mikhail Larionov, 1912. The State Tretyakov Gallery, Moscow

Figure 14: Armored Train in Action, Gino Severini, 1915. Oil on canvas, The Museum of Modern Art, New York

Figure 15: Jazz, Alexander Vasilyevich Shevchenko, 1935. Oil on cardboard, Russian Museum, Saint-Petersburg

Figure 16: Monument to the Third International, Vladimir Tatlin, 1920. Saint-Petersburg

Figure 17: Shroeder House, Gerrit Rietveld, 1924. Utrecht 
Rayonism in Early Modern Art - A Fleeting Ray of Light 